\title{
Intermolecular interactions between polyarylenephthalides surface and organic compounds of different nature by inverse gas chromatography data
}

\author{
Guskov V.Yu. ${ }^{1}$, Shaihitdinova Yu.F. ${ }^{1}$, Zilberg R.A. ${ }^{1}$, \\ Kraikin V.A. ${ }^{2}$, Maistrenko V.N. ${ }^{1}$ \\ ${ }^{I}$ Bashkir State University, Ufa \\ ${ }^{2}$ Ufa Institute of Chemistry UFRC RAS, Ufa
}

Received 14.11.2018

DOI: https://doi.org/10.17308/sorpchrom.2019.19/742

Polyarylenephthalides are a promising class of polymeric materials. They are soluble in organic solvents, but remain resistant to water, as well as to acids and bases. All this makes polyarylenphthalide promising materials for the formation of films on surfaces. However, for this it is necessary to first study the ability of polyarylenephthalides to different intermolecular interactions, as well as the polarity of their surface. Therefore, it is of interest to use the inverse gas chromatography method for studying the adsorption properties of the surface of polyarylenephthalates, as well as the evaluation of its conditional polarity.

Two polymers of the class of polyarylenephthalides were used as the studied samples: chlorinated (in position 4) poly (phthalidylidenefluorene) (OPS-236) and poly (phthalidylidene diphenyl) (PE-259). They are distinguished by the presence of a methylene group between two benzene rings. Inert solid support Chromaton NAW was used as a solid substrate for the deposition of polyarylenphthalide films. The application was carried out from chloroform by evaporation of the solvent at a temperature of $40^{\circ} \mathrm{C}$. The amount of the applied polymer was $1 \%$ by weight of the inert carrier.

The study was conducted by the method of inverse gas chromatography. Samples were introduced as diluted vapor-air mixtures at the limit of the detector sensitivity. This made it possible to measure the retention parameters in the Henry region and consider the interactions between sorbate molecules to be negligible. The relative conditional polarity of the surface and the contributions of various intermolecular interactions to adsorption free energy were estimated by the method of linear free energy relationship (LFER). From the obtained LFER-coefficients, the contributions of intermolecular interactions to the adsorption energy were calculated, and the relative conditional polarity of the surface was also estimated. The dispersion and specific component of the Helmholtz free energy of adsorption was calculated by the Dong method.

It has been established that adsorbents based on polyarylenephthalides are able to act as stationary phases for chromatography. It is shown that polyarylenephthalide films are capable of both dispersion and various specific interactions with organic molecules. The surface of polyarylenephthalides can be attributed to stationary phases of medium polarity, more polar than porous polymers based on styrene and divinylbenzene and less polar than silica gels.

Keywords: polyarylenephthalides, inverse gas chromatography, specific retention volume, polarity.

\section{Межмолекулярные взаимодействия поверхности полиари- ленфталидов с органическими веществами различной при- роды по данным обращённой газовой хроматографии}

\author{
Гуськов В.Ю. ${ }^{1}$. Шайхитдинова Ю.Ф. ${ }^{1}$, Зильберг Р.А. ${ }^{1}$, \\ Крайкин В.А. ${ }^{2}$, Майстренко В.Н. ${ }^{1}$ \\ ${ }^{1}$ ФГБОУ ВПО Башкирский государственный университет, Уфа \\ ${ }^{2}$ Уфимский институт химии УФИЦ РАН, Уфа
}

Полиариленфталиды представляют собой перспективный класс полимерных материалов. Они растворимы в органических растворителях, но при этом остаются устойчивыми к воде, а также к ки- 
слотам и основаниям. Всё это делает полиариленфталиды перспективными материалами для формирования плёнок на поверхностях. Однако для этого необходимо предварительно изучить способность полиариленфталидов к различным межмолекулярным взаимодействиям, а также полярность их поверхности. Поэтому представляет интерес применение метода обращённой газовой хроматографии для изучения адсорбционных свойств поверхности полиариленфтадилов, а также оценка её условной полярности.

В качестве исследуемых образцов были использованы два полимера класса полиариленфталидов: хлорированные (в положение 4) поли(фталидилиденфлуорен) (ОПС-236) и поли(фталидилидендифенил) (ПЭ-259). Они отличаются наличием метиленового мостика между двумя бензольными кольцами. В качестве твёрдой подложки для нанесения плёнок полиариленфталидов использовался инертный носитель Chromaton NAW. Нанесение проводилось из хлороформа путём упаривания растворителя при температуре $40{ }^{\circ} \mathrm{C}$. Количество наносимого полимера составило $1 \%$ от массы инертного носителя.

Исследование проводилось методом обращённой газовой хроматографии. Пробы вводились с виде разбавленных паровоздушных смесей на пределе чувствительности детектора. Это позволило измерить параметры удерживания в области Генри и считать взаимодействия между молекулами сорбата пренебрежимо малыми. Относительная условная полярность поверхности и вклады различных межмолекулярных взаимодействий в $\Delta \mathrm{F}$ оценивались методом линейного разложения энергии адсорбции (LFER). Из полученных LFER-коэффициентов рассчитывались вклады межмолекулярных взаимодействий в энергию адсорбции, а также оценивалась относительная условная полярность поверхности. Дисперсионную и специфическую составляющую свободной энергии Гельмгольца адсорбции также рассчитывали методом Донга. Установлено, что адсорбенты на основе полиариленфталидов способны выступать в качестве неподвижных фаз для хроматографии. Показано, что плёнки полиариленфталидов способны как к дисперсионным, так и к различным специфическим взаимодействиям с органическими молекулами. Поверхность полиариленфталидов можно отнести к неподвижным фазам средней полярности, более полярным, чем пористые полимеры на основе стирола и дивинилбензола и менее полярным, чем силикагели.

Ключевые слова: полиариленфталиды, обращённая газовая хроматография, удельный удерживаемый объём, полярность

\section{Introduction}

Polyarylenephthalides are a new promising type of soluble polymers. Polyarylenephthalides traditionally include aromatic polymers based on pseudochlorine hydrides. In this case, the pseudochlorine hydride group of the monomer is directly connected with the phthalide group, and the formation of a new bond during polycondensation, leading to the growth of the macromolecule, occurs directly with the carbon atom of the phthalide group [1]. Polyarylenphthalide thin films are electrically conductive, have high thermal stability, are resistant to water, acids and alkalis, and are soluble in many organic solvents [2]. Therefore, it is of interest to create adsorption materials based on them for the extraction of toxicants from acidic and alkaline media. However, for this it is necessary firstly to study the ability of polyarylenephthalides to different intermolecular interactions, as well as the polarity of their surface.

Inverse gas chromatography is one of the methods of studying the interactions between gas molecules and solids [3-5]. This method allows to calculate the thermodynamic characteristics of adsorption [6-8], to estimate the polarity of the surface and the contributions of various interactions to the adsorption energy [9-12], and also to obtain adsorption isotherms and calculate the monolayer capacity and the specific surface area of solids $[5$, $13,14]$. Therefore, the aim of this work is to study the polarity of polyarylenephthalates surface by inverse gas chromatography.

\section{Experiment}

Two polyarylenephthalides polymers were used as samples to study: chlorinated (in position 4) poly (phthalidylidenefluorene) (OPS-236) and poly (phthalidylidene diphenyl) 
(PE-259). The structural formulas of the monomer unit are shown in Fig. 1. They are distinguished by the presence of a methylene group between two benzene rings. Inert solid support Chromaton NAW was used as a solid substrate for the deposition of polyarylenphthalide films. The modification was carried out from chloroform by solvent evaporation at $40^{\circ} \mathrm{C}$. The amount of the applied polymer was $1 \%$ by weight of the inert solid support. Such modifier amount provides the full applying of solid support by polymers.

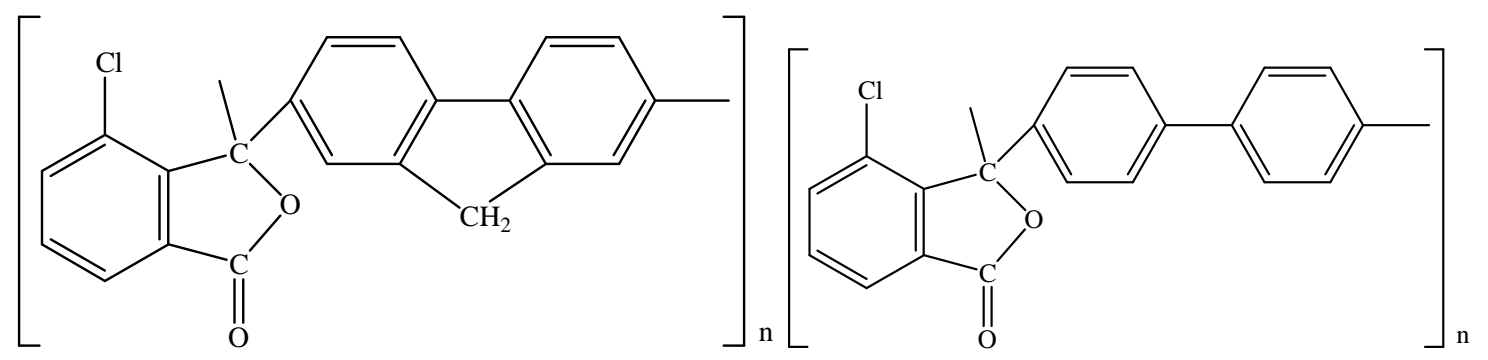

OPS-236 PE-259

Рис. 1. Polyarylenephthalides under study

Chromos GC-1000 chromatograph (Chromos, Dzerzhinsk, Russia) with a flame ionization detector was used. Stainless steel column measuring 1000x3 mm was used. The nitrogen carrier gas flow-rate was $20 \mathrm{ml} / \mathrm{min}$. The column temperature was $100^{\circ} \mathrm{C}$, the evaporator and detector temperature $-200^{\circ} \mathrm{C} . \mathrm{C}_{5}-\mathrm{C}_{10}$ and $\mathrm{C}_{12}$ n-alkanes, cyclohexane, cyclohexanone, benzene, toluene, $\mathrm{C}_{1}-\mathrm{C}_{8} \mathrm{n}$-alcohols, butanol-2, pentanol-2, isopropanol, isobutanol, isopentanol, tert-butyl alcohol, pyridine, ethyl acetate and butyl acetate were used as test sorbates. Before use, the column was conditioned for 10 hours at $100^{\circ} \mathrm{C}$ in a stream of nitrogen carrier gas. Samples were introduced as diluted vapor-air mixtures at the detector sensitivity limit. This made it possible to measure the retention parameters in the Henry region and consider the interactions between sorbate molecules to be negligible.

From the experimentally determined retention times $\left(\mathrm{t}_{\mathrm{R}}{ }^{0}, \mathrm{~min}\right)$, the retention volumes values were calculated using the following equation $V_{g}{ }^{0}, \mathrm{ml} / \mathrm{g}$ :

$$
V_{g}^{0}=\frac{\left(t_{R}^{0}-t_{m}\right) \cdot \omega}{m} \cdot \frac{T}{T_{c}}
$$

where $t_{m}$ - dead retention time, $\omega$ - carrier gas flow-rate, $\mathrm{ml} / \mathrm{min}, m$ - sorbent mass, $\mathrm{g}$, $T$ - column thermostat temperature, $\mathrm{K}, T_{c}$ - room temperature, $\mathrm{K}$.

The molar changes in the Helmholtz energies of adsorption $\Delta \mathrm{F}, \mathrm{kJ} / \mathrm{mol}$, were calculated as follows:

$$
\Delta F=-R T \ln V_{g}^{0}+R T,
$$

The relative conditional polarity of the surface and the contributions of various intermolecular interactions to $\Delta \mathrm{F}$ were estimated by the method of linear free energy relationship (LFER). In this method, the total adsorption energy is decomposed into dispersion $\left(\Delta \mathrm{F}_{\text {disp }}\right)$, electrostatic $\left(\Delta \mathrm{F}_{\mathrm{io}}\right.$, characterizes induction and orientation interactions $)$ and donoracceptor $\left(\Delta \mathrm{F}_{\mathrm{da}}\right)$ components:

$$
\Delta F=\Delta \mathrm{F}_{\text {disp }}+\Delta F_{\text {io }}+\Delta F_{d a}
$$

Each of the components can be expressed as a product of a coefficient characterizing the properties of the surface and the molecular descriptor describing certain characteristics of the sorbate molecule:

$$
\begin{aligned}
& -\Delta F_{\text {disp }}=K_{1} \alpha_{B}+K_{5}, \\
& -\Delta F_{i o}=K_{2}\left(\frac{2 \mu_{B}^{2}}{3 k T}+\alpha_{B}\right), \\
& -\Delta \mathrm{F}_{\mathrm{da}}=K_{3} W_{B}^{\alpha}+K_{4} W_{B}^{d},
\end{aligned}
$$


The general LFER equation can be derived as follows [11, 15]:

$$
-\Delta F=K_{1} \alpha_{B}+K_{2}\left(\frac{2 \mu_{B}^{2}}{3 k T}+\alpha_{B}\right)+K_{3} W_{B}^{\alpha}+K_{4} W_{B}^{d}+K_{5},
$$

where $K_{1}-K_{5}$ are the dispersion, induction and orientation, electron donor and electron acceptor coefficients of the sorbent surface respectively. The coefficient $\mathrm{K}_{5}$ also characterizes the dispersion interactions. $\alpha_{\mathrm{B}}, \mu_{\mathrm{B}}, \mathrm{W}_{\mathrm{B}}{ }^{\mathrm{a}}, \mathrm{W}_{\mathrm{B}}{ }^{\mathrm{d}}$ - polarizability, dipole moment, electron-acceptor and electron-donor constants of the sorbate, respectively.

The resulting equation has 5 unknowns. Therefore, a system of equations requires to solve it. Equation (7) can be written for any test sorbate with known molecular descriptors. To solve this equation in the case of OPS-236, the following set of test sorbates was used: hexane, heptane, octane, cyclohexane, benzene, toluene, ethanol, n-propanol, n-butanol, isopropanol, isobutanol and ethyl acetate. In the case of PE-259, the following series of alkanes were used: heptane, octane, nonane, and decane. This was due to zero retention of hexane and cyclohexane at experiment temperatures. The list of arenes and alcohols in the case of PE-259 is similar to OPS-236.

A system of 12 equations was solved by multiple regression analysis. 2 variants of regression analysis were used. In the first, the classical equation (7) was used. In the second, equation (7) was applied with the intercept $\mathrm{K}_{5}$ as zero by default. From the obtained coefficients, the contributions of intermolecular interactions to the adsorption energy were calculated; also the relative conditional polarity of the surface was estimated as follows:

$$
P=\frac{\sum_{i=o}^{12}\left(\left(\Delta \mathrm{F}_{\mathrm{io}}+\Delta \mathrm{F}_{\mathrm{da}}\right) / \Delta F\right.}{12}-P_{G C B}
$$

where 12 is the number of test sorbates used in the LFER calculation, $P_{G C B}$ is the conditional polarity of graphitized thermal soot, calculated with the same number of test sorbates.

The dispersion and specific component of the Helmholtz free energy of adsorption was calculated by the Dong method [9]. In this method, the dispersion component of the substance's adsorption energy $\left(\Delta F^{D}\right.$ disp, $\left.\mathrm{kJ} / \mathrm{mol}\right)$ is assumed to be equal to the adsorption energy of a hypothetical n-alkane with the same polarizability. The specific component of the adsorption energy $\left(\Delta F^{D}\right.$ spec, $\left.\mathrm{kJ} / \mathrm{mol}\right)$ is calculated as the difference between the total adsorption energy and its dispersion component.

\section{Results and discussion}

In Table 1 the values of the specific retention volume on the adsorbents samples studied were shown. As can be seen from the obtained data, on an inert solid support modified by OPS-236, the retention of all sorbates is significantly higher than in the case of PE-259. This is probably due to the presence of a methylene bridge between the benzene rings in OPS-236, which changes the spatial structure of the polymer on the surface. On the sample modified with PE-259, the low-boiling sorbates have zero retention, while on the OPS-236 the retention of the high-boiling sorbates was too high. Retention volumes increase in homologous series, while the retention of $n$-alcohols is greater than isoalcohols. In the case of OPS-236, the retention of n-butanol is 4 times greater than that of tert-butyl alcohol. Even more noticeable is the difference in retention in the case of PE259. On it, n-butanol has 6 times stronger $V_{g}{ }^{0}$ than isobutanol and butanol-2, and more than 70 times stronger than tert-butyl alcohol. On both sorbents, tert-butyl alcohol has retention noticeably lower than any other $\mathrm{C}_{4}$ alcohol. This is probably due to the greater ability of linear molecules to penetrate between polymer chains. For tert-butyl alcohol, only adsorption on the polymer surface is possible, while for other $\mathrm{C}_{4}$ alcohols, partial penetration of molecules into the volume of polyarylenephthalides takes place. 
Table 1. Specific retention volumes, $V_{g}^{0}, \mathrm{ml} / \mathrm{g}$, on the samples studied

\begin{tabular}{|c|c|c|c|c|c|}
\hline \multirow{2}{*}{ sorbate } & \multicolumn{2}{|c|}{$V_{g}^{0}$} & \multirow{2}{*}{$V_{g}^{0}$} & \multicolumn{2}{|c|}{} \\
\cline { 2 - 3 } \cline { 5 - 6 } & OPS-236 & PE-259 & sorbate & OPS-236 & PE-259 \\
\hline n-pentane & 9.9 & 0 & methanol & 9.7 & 0 \\
\hline n-hexane & 15.2 & 0 & ethanol & 14.4 & 0.38 \\
\hline n-heptane & 29.3 & 0.55 & n-propanol & 33 & 0.61 \\
\hline n-octane & 62 & 2.3 & n-butanol & 98 & 4.3 \\
\hline n-nonane & 162 & 3.5 & n-pentanol & 243 & 9.2 \\
\hline n-decane & 660 & 22.6 & n-hexanol & 331 & 18.5 \\
\hline n-dodecane & - & 44 & n-heptanol & - & 27.6 \\
\hline cyclohexane & 13.6 & 0 & n-octanol & - & 45 \\
\hline benzene & 32.1 & 1.8 & 2-butanol & 28.7 & 0.69 \\
\hline toluene & 107 & 5.5 & 2-pentanol & 103 & 3.4 \\
\hline cyclohexanon & - & 7.5 & i-propanol & 26.7 & 0.26 \\
\hline ethyl acetate & 27 & 0.55 & i-butanol & 57 & 0.70 \\
\hline butyl acetate & 172 & 2.8 & i-pentanol & 157 & 2.2 \\
\hline pyridine & 122 & 2.5 & tert- butanol & 15.8 & 0.06 \\
\hline
\end{tabular}

From the table data it is noticeable that on both polymer surfaces benzene and toluene have higher retention than hexane and heptane, respectively. So, on OPS-236, the benzene retention volume is more than 2 times higher than $V_{g}{ }^{0}$ of hexane; on PE-259 unlike benzene hexane has zero retention. At the same time, the retention of toluene is 10 times more than heptane. At OPS-236, there is only a fourfold difference in retention of toluene and heptane. The reverse is usually observed - n-alkanes are retained stronger than arenes. The strong retention of the latter on the stationary phases studied is probably due to $\pi-\pi$ interactions between the benzene rings of polyarylenephthalides and arenes.

From $\Delta F$ vs. the number of carbon atoms in the homologous series $n$ linear dependence, the increments of one methylene group in adsorption energy were calculated. In the case of PE-259, they were slightly higher than for OPS-236: $3.5 \mathrm{~kJ} / \mathrm{mol}$ versus $3.2 \mathrm{~kJ} / \mathrm{mol}$ for alkanes; $3.3 \mathrm{~kJ} / \mathrm{mol}$ versus $3.1 \mathrm{~kJ} / \mathrm{mol}$ for n-alcohols and $4.2 \mathrm{~kJ} / \mathrm{mol}$ versus $3.5 \mathrm{~kJ} / \mathrm{mol}$ for iso-alcohols. Higher values of the methylene group increment for iso-alcohols are probably due to the fact that the length of the linear part of the molecule increases in the homologous series of such compounds. The linear region of the molecule can freely penetrate between the polymer chains, which cause an additional contribution to retention compared to lower homologs.

The results of the LFER calculations are given in Tables 2 and 3. It was found that the use of the LFER method without taking into account the intercept leads to low correlation coefficients and difficulties to interpret data. Therefore, only the data obtained with intercept were used for the analysis. As can be seen from the obtained results, in the case of both polymers, dispersion interactions make the greatest contribution to the energy of adsorption of alkanes and arenes. For benzene, donor - acceptor interactions make a greater contribution than induction and orientational interactions, in the case of toluene, the contributions of various specific interactions to the last dipole moment are equalized.

For alcohols and ethyl acetate, specific interactions prevail. Comparison of the contributions of donor-acceptor interactions to the alcohols adsorption energy on the studied adsorbents shows that the OPS-236 sample has a greater affinity for being an electron density donor than PE-259. In general, the polarities of both polyarylenephthalides are close, and are numerically between porous polymers based on styrene and divinylbenzene $\left(\mathrm{P}^{\prime}=15\right)$ and silica gels $\left(\mathrm{P}^{\prime}=30\right)$. Such values of polarity are due to the presence of carbonyl groups and chlorine atoms in polymers capable of specific intermolecular interactions. 
Table 2. The intermolecular interactions impacts in $\Delta \mathrm{F}$ of organic molecules adsorption, $\%$, on inert solid support, modified by polyarylenephthalide OPS-236, by LFER calculations with intercept in equation (7)

\begin{tabular}{|c|c|c|c|c|}
\hline sorbate & dispersive & $\begin{array}{c}\text { induction+ } \\
\text { orientational }\end{array}$ & electron-donor & $\begin{array}{c}\text { electrona- } \\
\text { cceptor }\end{array}$ \\
\hline n-hexane & 85 & 15 & 0 & 0 \\
\hline n-heptane & 85 & 15 & 0 & 0 \\
\hline n-octane & 84 & 16 & 0 & 0 \\
\hline benzene & 71 & 12 & 0 & 17 \\
\hline cyclohexane & 85 & 15 & 0 & 0 \\
\hline toluene & 68 & 16 & 0 & 16 \\
\hline ethanol & 31 & 27 & 38 & 0 \\
\hline n-propanol & 35 & 26 & 36 & 0 \\
\hline n-butanol & 39 & 26 & 37 & 0 \\
\hline i-propanol & 35 & 28 & 35 & 0 \\
\hline i-butanol & 39 & 26 & 0 & 32 \\
\hline ethyl acetate & 38 & 29 & \\
\hline r & \multicolumn{3}{|l}{0.9539} & \\
\hline P' &
\end{tabular}

Table 3. The intermolecular interactions impacts in $\Delta \mathrm{F}$ of organic molecules adsorption, $\%$, on inert solid support, modified by polyarylenephthalide PE-259, by LFER calculations with intercept in equation (7)

\begin{tabular}{|c|c|c|c|c|}
\hline sorbate & dispersive & $\begin{array}{c}\text { induction+ } \\
\text { orientational }\end{array}$ & electron-donor & $\begin{array}{c}\text { electrona- } \\
\text { cceptor }\end{array}$ \\
\hline n-heptane & 85 & 15 & 0 & 0 \\
\hline n-octane & 85 & 15 & 0 & 0 \\
\hline n-nonane & 84 & 16 & 0 & 0 \\
\hline benzene & 74 & 11 & 0 & 14 \\
\hline cyclohexane & 84 & 16 & 0 & 0 \\
\hline toluene & 71 & 15 & 0 & 14 \\
\hline ethanol & 39 & 26 & 35 & 0 \\
\hline n-propanol & 42 & 25 & 33 & 0 \\
\hline n-butanol & 44 & 25 & 31 & 0 \\
\hline i-propanol & 42 & 27 & 30 & 0 \\
\hline i-butanol & 44 & 25 & 0 & 29 \\
\hline ethyl acetate & 43 & 28 & \\
\hline r & \multicolumn{2}{|l}{0.9430} & \\
\hline P' & \multicolumn{2}{l}{} \\
\hline
\end{tabular}

The data on the dispersion and specific components of the adsorption energy calculated by the Dong method are shown in Table 4. As follows from the data obtained, for both samples the specific component of the adsorption energy has a negative sign, indicating that the process is spontaneous. The specific component of adsorption energy of arenes on a sample modified with PE-259 is $4 \mathrm{~kJ} / \mathrm{mol}$ more in absolute value than on a sample based on OPS-236. This is probably due to the presence of the methylene bridge in the latter, which blocks the $\pi-\pi$ interaction. It is interesting to note that the $-\Delta F^{D}$ spec for $\mathrm{n}$-alcohols is more on PE-259, and for iso-alcohols - on OPS-236. This indicates steric difficulties in the interaction of the hydroxyl group with the functional groups of PE-259. Especially great steric difficulties are for tert-butyl alcohol. 
Table 4. Dispersive and specific components of adsorption energy, $\mathrm{kJ} / \mathrm{mole}$, calculated by Dong method

\begin{tabular}{|c|c|c|c|c|}
\hline \multirow{2}{*}{ sorbate } & \multicolumn{2}{|c|}{ OPS-236 } & \multicolumn{2}{c|}{ PE-259 } \\
\cline { 2 - 5 } & $\Delta F_{\text {disp }}^{D^{2}}$ & $\Delta F_{\text {spec }}^{D}$ & $\Delta F_{\text {disp }}$ & $\Delta F_{\text {spec }}$ \\
\hline benzene & -7.5 & -6.1 & 8.3 & -10.5 \\
\hline toluene & -10.9 & -7.4 & 4.6 & -11.3 \\
\hline methanol & 4.5 & -13.5 & - & - \\
\hline ethanol & 1.1 & -11.6 & 17.7 & -13.8 \\
\hline n-propanol & -2.1 & -11.6 & 14.2 & -12.2 \\
\hline n-butanol & -5.4 & -12.7 & 10.7 & -16.4 \\
\hline n-pentanol & -8.6 & -13.0 & 7.2 & -15.9 \\
\hline n-hexanol & -11.8 & -11.0 & 3.6 & -15.1 \\
\hline n-heptanol & - & - & 0.1 & -13.2 \\
\hline n-octanol & - & - & -3.4 & -11.6 \\
\hline 2-butanol & -5.2 & -8.0 & 10.9 & -9.4 \\
\hline 2-pentanol & -8.2 & -10.0 & 7.5 & -12.4 \\
\hline i-propanol & -1.8 & -11.2 & 14.6 & -9.3 \\
\hline i-butanol & -5.2 & -10.7 & 10.9 & -9.5 \\
\hline i-pentanol & -8.2 & -11.6 & 7.5 & -10.7 \\
\hline tert- butanol & -5.2 & -5.7 & 10.9 & 0.2 \\
\hline pyridine & -6.1 & -12.8 & 9.9 & -13.5 \\
\hline ethyl acetate & -6.1 & -6.9 & 9.9 & -7.5 \\
\hline butyl acetate & -12.6 & -7.7 & 2.9 & -6.9 \\
\hline cyclohexanon & - & - & 6.0 & -13.9 \\
\hline
\end{tabular}

For the majority of compounds on PE-259 and the first two homologues of alcohols on OPS-236, a positive $\Delta F^{D}$ disp value was observed. This correlates with low values of specific retention volumes, and explained with less opportunities for the penetration of organic molecules into the volume of the polymer in the case of PE-259. Comparison of the dispersion and specific components also testifies to the high polarity of the polyarylenephthalides surface.

\section{Conclusion}

It has been established that adsorbents based on polyarylenephthalides are capable of acting as stationary phases for chromatography. It is shown that polyarylenephthalide films are capable of both dispersion and various specific interactions with organic molecules. The surface of polyarylenephthalides can be attributed to stationary phases of medium polarity, more polar than porous polymers based on styrene and divinylbenzene and less polar than silica gels.

This work was supported by Russian foundation for basic research (project No. 18-03-00537)

Работа выполнена при поддержке Российского фонда фундаментальных исследований (проект № 18-03-00537)

\section{References}

1. Salazkin S.N., Shapohnikova V.V., Chemistry, 2008, Vol. 50, pp. 243-259. doi: Machulenko L.N., Gileva N.G., Kraikin V.A., 10.1007/s11498-008-3002-y

Lachinov A.N., Polymer Science, Series B, 2. Salazkin S.N., Polymer Science-Series B, 2004, Vol. 46, pp. 203-223. 
3. Ho R., Heng J.Y.Y., KONA powder and particle journal, 201310.14356/kona.2013016, pp. 164-180. doi: 10.14356/kona.2013016

4. Mohammadi-Jam S., Waters K.E., $A d v$. Colloid Interf. Sci., 2014, Vol. 212, pp. 21-44. doi: 10.1016/j.cis.2014.07.002

5. Thielmann F., J. Chromatogr. A, 2004, Vol. 1037, pp. 115-123. doi: 10.1016/j.chroma.2004.03.060

6. Onuchak L.A., Tugareva D.A., Kapralova T.S., Kuraeva Y.G. et al., Protection of metals and physical chemistry of surfaces, 2015, Vol. 51, pp. 944-950. doi: 10.1134/S2070205115060155

7. Onuchak L.A., Kapralova T.S., Kuraeva Y.G., Belousova Z.P. et al., Russian journal of physical chemistry A, 2015, Vol. 89, pp. 23042312. doi: $10.7868 / \mathrm{S} 0044453715120225$

8. Kiselev A.V., Yashin Y.I. Gas adsorption chromatography. New York, Plenum Press, 1969.

Гуськов Владимир Юрьевич - к.х.н., доцент кафедры аналитической химии химического факультета Башкирского государственного университета; тел.: (347) 273-67-21, Уфа

Шайхитдинова Юлия Фанилевна - магистрант кафедры аналитической химии Башкирского государственного университета, тел.: (347) 273-67-21, Уфа

Зильберг Руфина Алексеевна - к.х.н., доцент кафедры аналитической химии химического факультета Башкирского государственного университета; тел.: (347) 273-67-21, Уфа

Крайкин Владимир Александрович - д.х.н., проф. зав. лабораторией синтеза функциональных полимеров Уфимского института химии УФИЦ РАН, Уфа.

Майстренко Валерий Николаевич - д.х.н., профессор, заведущий кафедры аналитической химии химического факультета Башкирского государственного университета; тел.: (347) 273 67-21, Уфа
9. Dong S., Brendle M., Donnet J.B., Chromatograhia, 1989, Vol. 28, pp. 469-472.

10. Abraham M.H., Ibrahim A., Zissimos A.M., J. Chromatogr. A, 2004, Vol. 1037, pp. 29-47. doi: 10.1016/j.chroma.2003.12.004

11. Larionov O.G., Petrenko V.V., Platonova N.P., J. Chromatogr. A, 1991, Vol. 537, pp. 295-303. doi: 10.1016/S0021-9673(01)88903-2

12. Kudasheva F. Kh., Gus'kov V.Yu., Valinurova E.R. Adsorbciya. Theoriya i praktika. Ufa, RIC BashGU, 2014, 208 p.

13. Kondor A., Dallos A., J. Chromatogr. A, 2014, Vol. 1362, pp. 250-261. doi: 10.1016/j.chroma.2014.08.047

14. Gus'kov V.Y., Ganieva A.G., Kudasheva F.K., Colloids Surf. A, 2017, Vol. 513, pp. 95101. doi: 10.1016/j.colsurfa.2016.11.039

15. Gus'kov V.Y., Kudasheva F.K., Mozgovoi O.S., Protection of Metals and Physical Chemistry of Surfaces, 2013, Vol. 49, pp. 639641. doi: 10.1134/S207020511306004X

Gus'kov Vladimir Yu. - PhD of Chemistry, Bashkir State University, Ufa, E-mail: guscov@mail.ru

Shaihitdinova Yulia F. - master student of the department of Analytical Chemistry, Bashkir State University, Ufa, E-mail: shaihitdinova2015@yandex.ru

Zilberg Rufina A. - PhD of Chemistry, Bashkir State University, Ufa, E-mail: zilbergra@yandex.ru

Kraikin Vladimir A. - the Head of laboratory of functional polymers synthesis, Ufa Institute of Chemistry UFRC RAS, Ufa

Maistrenko Valery N. - the Head of Analytical Chemistry Chair, Bashkir State University, Ufa, Email: $\underline{\mathrm{v} \_ \text {maystrenko@mail.ru }}$ 